\title{
Desain Self-Propelled Barge Sebagai Fasilitas Pengangkut Block untuk Galangan Kapal dari Batam ke Singapura
}

\author{
Rakadrian Nugraha Buana, Ardi Nugroho Yulianto, dan Hesty Anita Kurniawati \\ Departemen Teknik Perkapalan, Fakultas Teknologi Kelautan, Institut Teknologi Sepuluh Nopember (ITS) \\ e-mail: tita@na.its.ac.id
}

\begin{abstract}
Abstrak-Salah satu jasa yang disediakan oleh galangangalangan kapal di Batam dan Singapura adalah layanan pembuatan blok-blok kapal ataupun bangunan offshore dimana blok tersebut akan difabrikasi di sebuah galangan lalu diantar ke galangan lainnya untuk kemudian dilakukan joint erection. Dalam jurnal ini akan dibahas sebuah moda transportasi berbentuk self-propelled barge yang berfungsi untuk mengangkut blok-blok tersebut dengan tujuan meringankan biaya produksi yang disebabkan oleh penyewaan tongkang beserta tugboat. Analisis teknis yang dibahas yaitu penentuan ukuran utama kapal, koefisien bentuk, hambatan dan propulsi kapal, freeboard, stabilitas kapal, trim, serta prosedur loading dan off-loading. Serta perhitungan ekonomis yang dibahas yaitu perhitungan biaya pembangunan kapal, penentuan harga sewa kapal, break even point, serta perbandingan harga dengan moda transportasi yang sudah ada. Ukuran utama kapal yang didesain yaitu panjang per pendicular (LPP): 89,2 meter, lebar (B): 21,1 meter, sarat (T): 2 meter, dan tinggi $(\mathrm{H}): 4,3$ meter, dengan kecepatan : 10 knots. Kapal ini memiliki kapasitas untuk mengangkut tiga blok bangunan kapal ataupun bangunan offshore yang memiliki ukuran maksimal luasan tiap blok $20 \mathrm{x}$ 18 meter dan berat maksimal 270 ton. Harga penyewaan dari self-propelled barge ini yaitu Rp.6.700.000.000.
\end{abstract}

Kata Kunci-Blok, Self-propelled Barge, Loading, Off-Loading, Batam, Singapura.

\section{PENDAHULUAN}

$\mathrm{B}$ ATAM merupakan salah satu kota industri yang ada di Indonesia, lebih tepatnya yaitu industri perkapalan. Tidak jarang juga perusahaan galangan-galangan kapal di Batam menerima pesanan dari luar negeri sebagai contoh negara tetangga kita yaitu Singapura. Beberapa jasa yang dilakukan perusahaan galangan-galangan kapal di Batam salah satunya adalah Steel Structure Fabrication. Steel Structure Fabrication adalah jasa pembangunan satuan block atau lebih untuk perakitan kembali di daerah lain yaitu seperti pembangunan block-block kapal atau pembangunan block-block bangunan offshore. Dalam proses pengiriman block-block ini, perusahaan galangan kapal banyak yang menggunakan jasa pengiriman menggunakan kapal tongkang, terkadang mereka pun menyewa jasa tersebut dari luar negeri. Dan rata-rata dari bisnis penyewaan tongkang harus menyewa kapal tugboat juga untuk memandu tongkang tersebut. Dengan begitu akan menambah biaya ekstra dalam pembangunan block-block tersebut.

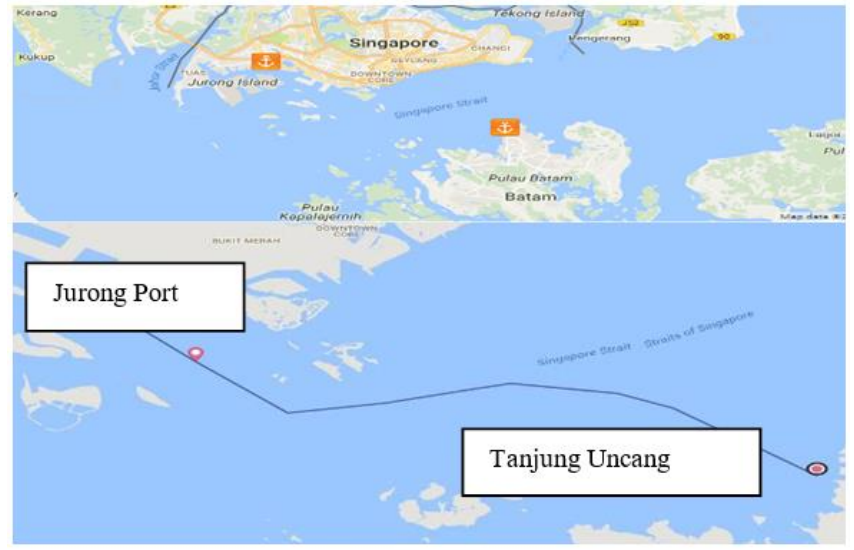

Gambar 1. Rute pelayaran.

Sehubungan dengan adanya kasus tersebut, maka dalam pekerjaan ini akan dibahas mengenai desain self-propelled barge yang mampu mengurangi biaya penyewaan moda transportasi pengiriman blok-blok tersebut serta mampu bekerja secara optimal dan fungsional.

Adapun tujuan dari pekerjaan ini adalah untuk mendapatkan ukuran utama dari self-propelled barge, perhitungan teknis seperti hambatan dan propulsi kapal, trim, freeboard, serta stabilitas, dan juga perhitungan ekonomis serta analisis perbandingannya dengan kapal pengangkut yang sudah ada. Dari ukuran utama yang sudah didapatkan kemudian dijadikan acuan untuk membuat gambar rencana umum, gambar rencana garis, serta gambar model 3D dari self-propelled barge tersebut.

\section{TINJAUAN PUSTAKA}

\section{A. Pendekatan Desain}

Dalam proses mendesain kapal, digunakan pula Teknik berulang yang prosesnya terangkum dalam sebuah alur melingkar disebut Spiral Design. Proses berulang ini bertujuan untuk menghasilkan sebuah hasil desain yang maksimal dan sesuai keinginan. Didalam diagam spiral design terdapat 4 pembagian proses yaitu design statement, concept design, preliminary design, contract design, dan detail design [1].

\section{B. Self-Propelled Barge}

Self-Propelled Barge (SPB) adalah salah satu jenis dari tongkang (barge) yang di desain dengan bentuk lambung dan 
bagian bawah yang datar, namun perbedaan dengan tongkang lainnya SPB ini memiliki tenaga penggerak sendiri sehingga tidak memerlukan bantuan tug boat untuk bergerak.Dengan begitu kapal slef-propelled barge ini memiliki keunggulan dalam bermanuver daripada tongkang dan tug boat biasa yang sudah ada [2].

\section{Rute Pelayaran}

Kota Batam merupakan kawasan yang terkenal dengan industri galangan kapalnya. Dalam setahun perusahaan galangan mengerjakan sekitar seribu unit kapal tongkang dan tug boat. Industri galangan kapal di Batam dapat dikatakan sangat berkembang. Beberapa galangan kapal di Batam melakukan jasa steel structure fabrication. Pemesan dari bangunan blok-blok kapal darn bangunan offshore ini kebanyakan dari luar Indonesia, salah satunya adalah Singapura. Alasan adanya jasa steel structure fabrication ini adalah untuk dilakukannya join erection di galangan Singapura. Rute pelayaran dapat dilihat pada Gambar 1.

\section{METODOLOGI}

\section{A. Pengumpulan Data}

Dalam pengerjaan Jurnal ini dilakukan pengambilan data. Data yang digunakan merupakan data sekunder yaitu data yang didapatkan tidak secara pengukuran langsung di lapangan melainkan dari galangan kapal, jasa penyewaan tongkang dan tug boat, serta jasa penyewaan crane.

\section{B. Pengolahan Data}

Setelah terkumpulnya data yang dibutuhkan maka selanjutnya adalah melakukan perhitungan dan analisis. Perhitungan yang dibahas pada jurnal ini adalah perhitungan teknis dan ekonomis. Juga dilakukan analisis pada perhitungan ekonomis untuk kemudian dilakukan perbandingan harga dengan jasa penyewaan yang sudah ada. Perhitungan teknis dilakukan dengan melakukan sketsa dari layout ukuran utama awal untuk kemudian dilakukan perhitungan lebih menyeluruh seperti perhitungan stabilitas, trim, freeboard, hambatan dan propulsi kapal, serta koreksi displacement. Setelah didapatkan semua perhitungan maka dilakukan penggambaran desain rencana garis, rencana umum, serta model 3D. Lalu terakhir dilakukan penentuan dari securing muatanPerhitungan ekonomis dilakukan dengan menghitung biaya pembangunan dan biaya operasional dari kapal ini untuk kemudian dilanjutkan menghitung net present value, break even point, internal rate of return, profitability index, dan payback period. Perhitungan ekonomis dilakukan pada jangka waktu 5 tahun.

\section{Diagram Alir}

Diagram alir dari proses pengerjaan jurnal ini dapat dilihat pada Gambar 2.

\section{ANALISIS TEKNIS}

\section{A. Penentuan Payload}

Kapasitas angkut dari self-propelled barge ini yaitu

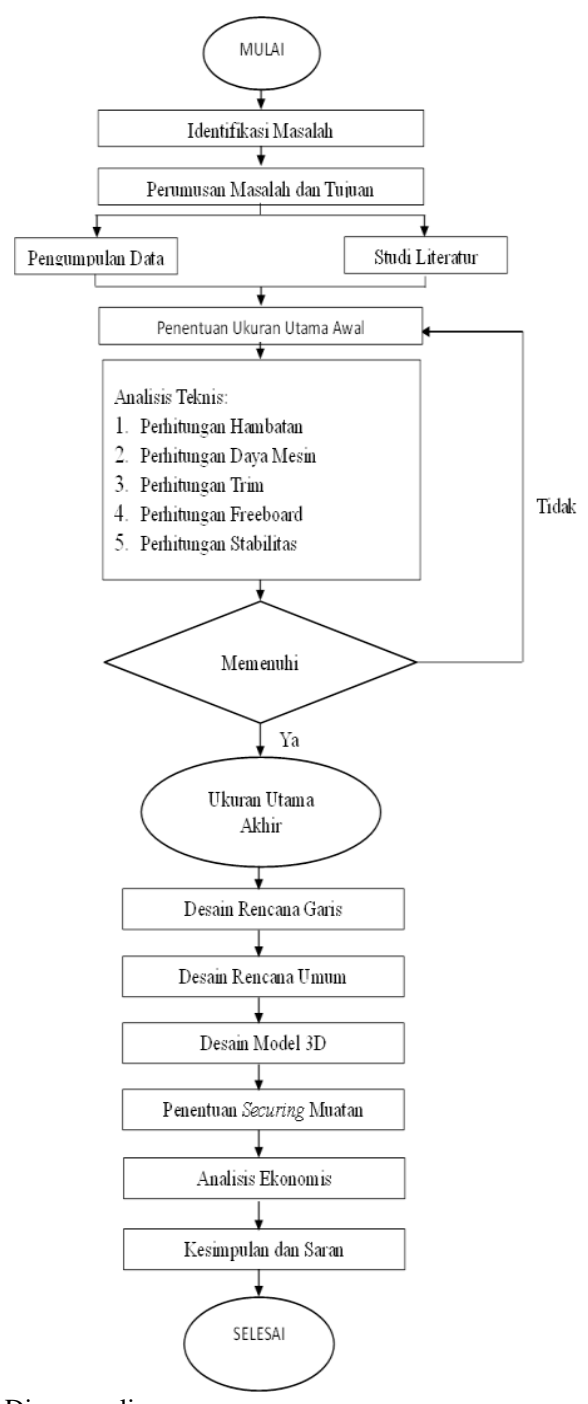

Gambar 2. Diagram alir.

mengangkut 3 buah blok bangunan kapal maupun bangunan offshore ditentukan dari rata-rata manifest per satu kali pengiriman. Ketentuan maksimal dari ukuran dan berat dari satu blok dapat dilihat pada

Tabel 1.

Tabel 1 Ukuran Maksimum Blok

\begin{tabular}{ccc}
\hline \hline Komponen Blok & Nilai & Satuan \\
\hline Ukuran luasan alas & $20 \times 18$ & $\mathrm{~m}^{2}$ \\
Berat & 270 & ton \\
\hline \hline
\end{tabular}

\section{B. Penentuan Ukuran Utama}

Tabel 2.

Ukuran Utama Kapal

\begin{tabular}{lcc}
\hline \hline Komponen & Nilai & Satuan \\
\hline $\mathrm{L}_{\mathrm{PP}}$ & 89,2 & $\mathrm{~m}$ \\
$\mathrm{~B}$ & 21,1 & $\mathrm{~m}$ \\
$\mathrm{H}$ & 4,3 & $\mathrm{~m}$ \\
$\mathrm{~T}$ & 1,5 & $\mathrm{~m}$ \\
$\mathrm{~V}_{\mathrm{S}}$ & 10 & knot \\
$\mathrm{C}_{\mathrm{B}}$ & 0,818 & \\
$\mathrm{C}_{\mathrm{M}}$ & 0,994 & \\
$\mathrm{C}_{\mathrm{P}}$ & 0,823 & \\
$\mathrm{C}_{\mathrm{WP}}$ & 0,887 & \\
$\mathrm{LCB}$ & 42,39 & m dari FP
\end{tabular}




\begin{tabular}{lll} 
Displacement & $2,322.95$ & $\mathrm{~m}^{3}$ \\
\hline \hline
\end{tabular}

Setelah ditentukannya kapasitas payload yang akan diangkut pada kapal self-propelled barge tersebut maka selanjutnya adalah dilakukannya penentuan ukuran utama kapal. Ukuran utama kapal didapatkan melalui proses pengujian berulang. Ukuran utamadan koefisien kapal ini dapat dilihat pada Tabel 2.

\section{Pemilihan Tenaga Penggerak}

Perhitungan daya yang dibutuhkan kapal ini didapatkan sekitar $918 \mathrm{~kW}$. Mesin induk yang akan dipilih harus mempunyai kapasitas daya dorong yang harus bisa menghasilkan daya tersebut. Mesin yang dipilih adalah marine engine dengan merk Caterpillar yang mempunyai daya sebesar $1050 \mathrm{~kW}$ dan berat 10,5 ton. Kemudian dibutuhkan juga tenaga pendukung yaitu berupa genset dengan asumsi daya 25\% dari daya mesin induk. Mesin tenaga pendukung yang dipilih yaitu genset dengan merk Caterpillar dengan daya $340 \mathrm{~kW}$ dan berat 1,7 ton.

\section{Perhitungan Berat Kapal}

Perhitungan berat kapal dibagi menjadi dua yaitu lightweight (LWT) dan deadweight (DWT). Lightweight merupakan berat kapal kosong tanpa muatan yang berarti hanya terdiri dari berat struktur kapal tersebut, berat isntalasi permesinan, serta berat dari perlengkapan kapal itu sendiri. Deadweight merupakan berat dari muatan kapal yang akan dibawa selama perjalanan berlangsung yaitu terdiri dari payload, bahan bakar mesin, kebutuhan awak kapal, serta air bersih. Untuk perhitungan LWT kapal ini didapatkan sebesar $1.372,436$ ton dan perhitungan DWT kapal didapatkan sebesar 1.001,513 ton.

\section{E. Perhitungan Freeboard}

Freeboard merupakan selisih tinggi kapal antara yang tercelup di dalam air dan yang tidak. Perhitungan freeboard mengacu aturan dari International Maritime Organization dalam konvensi International Convention on Load Lines (ICLL). Hasil perhitungan didapatkan freeboard minimal dari kapal ini adalah 1,216 meter [3].

\section{F. Penentuan Load Case}

Pemakaian kapal ini dapat dibagi menjadi empat kasus atau yang biasa dinamakan load case. Load Case A yaitu keadaan dimana saat kapal tidak membawa muatan sama sekali. Load Case $\mathrm{B}$ adalah dimana saat kapal hanya membawa muatan satu blok bangunan. Load Case C adalah dimana saat kapal hanya membawa muatan dua blok bangunan. Load Case D adalah dimana saat kapal membawa muatan penuh atau membawa tiga blok bangunan. Load Case E adalah dimana saat kapal membawa muatan satu mesin induk, dua mesin pendukung, dan dua blok bangunan. Load Case F adalah dimana saat kapal membawa satu mesin induk, dua mesin pendukung, dan satu blok bangunan. Load Case G adalah dimana saat kapal membawa muatan satu mesin induk dan dua mesin pendukung.Untuk tiap-tiap load case juga dilakukan variasi muatan lain pada kondisi $100 \%$ dan $10 \%$. Gambar ilustrasi dapat dilihat pada Gambar 3.
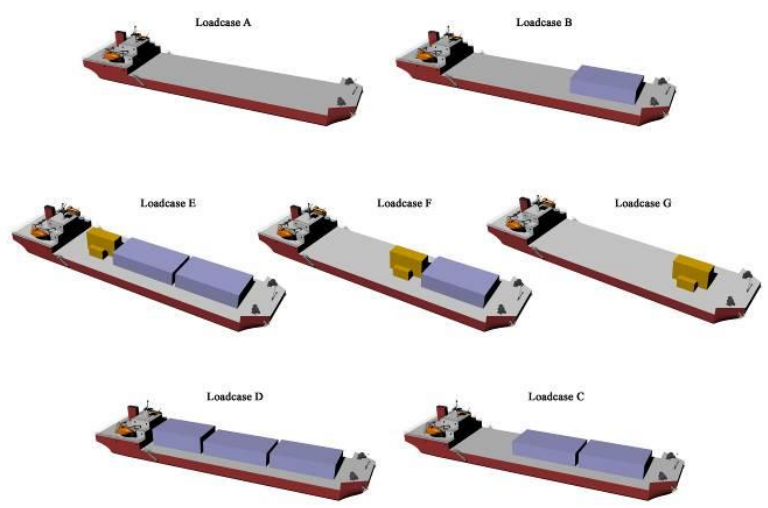

Gambar 3. Ilustrasi Load Case.

\section{G. Perhitungan Trim}

Trim adalah selisih antara sarat pada bagian depan dan bagian belakang sebuah kapal. Fenomena ini terjadi dikarenakan pembagian beban yang tidak merata di atas kapal untuk bagian depan maupun bagian belakang kapal. Aturan yang disyaratkan oleh IMO dalam Safety of Lives at Sea (SOLAS) adalah nilai trim tidak melebihi dari $0,5 \%$ panjang garis air kapal [3].

Untuk hasil dari perhitungan trim tiap-tiap load case dapat dilihat pada Tabel 3.

Tabel 3.

Hasil Perhitungan Trim

\begin{tabular}{lccc}
\hline \hline \multicolumn{1}{c}{ Load Case } & Hasil & Kriteria & Ket. \\
\hline Load Case A $(100 \%)$ & 0,216 & & Accepted \\
Load Case A $(10 \%)$ & 0,253 & & Accepted \\
Load Case B $(100 \%)$ & 0,121 & & Accepted \\
Load Case B $(10 \%)$ & 0,164 & & Accepted \\
Load Case C $(100 \%)$ & 0,340 & & Accepted \\
Load Case C $(10 \%)$ & 0,316 & & Accepted \\
Load Case D $(100 \%)$ & 0,156 & $<0,403$ & Accepted \\
Load Case D $(10 \%)$ & 0,114 & & Accepted \\
Load Case E $(100 \%)$ & 0,133 & & Accepted \\
Load Case E $(10 \%)$ & 0,092 & Accepted \\
Load Case F $(100 \%)$ & 0,156 & Accepted \\
Load Case F $(10 \%)$ & 0,152 & Accepted \\
Load Case G $(100 \%)$ & 0,005 & Accepted \\
Load Case G $(10 \%)$ & 0,038 & Accepted \\
\hline \hline
\end{tabular}

\section{H. Perhitungan Stabilitas}

Stabilitas kapal merupakan perhitungan bagaimana karakteristik keseimbangan kapal. Untuk kriteria stabilitas kapal juga diatur oleh IMO dalam Intact Stability Code (ISC). Perhitungan stabilitas juga dilakukan untuk tiap-tiap load case yang telah ditentukan. Kriteria yang dihitung ada lima yaitu, sudut maksimum pada sudut 30 derajat (I), sudut maksimum pada sudut 40 derajat (II), sudut maksimum pada sudut antara 30 dan 40 derajat (III), maksium GZ pada sudut 30 atau lebih (IV), sudut maksimum GZ (V), jarak GMT (VI) [4].

Hasil perhitungan stabilitas tiap-tiap kondisi dapat dilihat pada Tabel 4. 


\section{Penentuan Securing}

Securing adalah cara pengamanan muatan yang digunakan pada kapal saat berlayar. Penentuan securing muatan juga diatur menurut IMO dalam. Pengamanan dilakukan pada

Tabel 4.

Hasil Perhitungan Stabilitas

\begin{tabular}{lcccc}
\multicolumn{5}{c}{ Hasil Perhitungan Stabilitas } \\
\hline \hline Load Case & I & II & III & Ket. \\
\hline A100\% & 139,11 & 191,36 & 52,25 & Accepted \\
A10\% & 177,19 & 214,79 & 58,69 & Accepted \\
B100\% & 129,27 & 177,36 & 48,04 & Accepted \\
B10\% & 129,31 & 177,19 & 47,872 & Accepted \\
C100\% & 99,761 & 137.89 & 38,13 & Accepted \\
C10\% & 99,595 & 137.54 & 37,94 & Accepted \\
D100\% & 95,06 & 131,07 & 36,02 & Accepted \\
D10\% & 95,07 & 130,98 & 35,918 & Accepted \\
E100\% & 113,26 & 154,85 & 41,59 & Accepted \\
E10\% & 113,36 & 154,89 & 41,528 & Accepted \\
F100\% & 120,49 & 164,95 & 44,46 & Accepted \\
F10\% & 120,52 & 164,85 & 44,33 & Accepted \\
G100\% & 128,39 & 175,66 & 47,27 & Accepted \\
G10\% & 128,38 & 175,83 & 47,45 & Accepted \\
Kriteria & $\geq 3,151$ & $\geq 5,157$ & $\geq 1,719$ & \\
Load Case & IV & V & VI & Ket. \\
A100\% & 5.55 & 18,2 & 39,47 & Accepted \\
A10\% & 6,2 & 22,7 & 35,849 & Accepted \\
B100\% & 5,171 & 19,1 & 33,475 & Accepted \\
B10\% & 5.157 & 19.1 & 33,719 & Accepted \\
C100\% & 4,175 & 20,9 & 28,852 & Accepted \\
C10\% & 4,159 & 20.9 & 28,727 & Accepted \\
D100\% & 3,967 & 21,8 & 24,732 & Accepted \\
D10\% & 3,969 & 20.9 & 24,902 & Accepted \\
E100\% & 4,555 & 20,9 & 24,767 & Accepted \\
E10\% & 4,551 & 20,9 & 24,942 & Accepted \\
F100\% & 4,834 & 20,9 & 28,536 & Accepted \\
F10\% & 4,832 & 20,9 & 28,741 & Accepted \\
G100\% & 5,104 & 19,1 & 33,488 & Accepted \\
G10\% & 5,119 & 19,1 & 33,217 & Accepted \\
Kriteria & $\geq 0,200$ & $\geq 15$ & $\geq 0,15$ & \\
\hline \hline & & & & \\
\hline
\end{tabular}

bagian sisi atas dan sisi samping tiap-tiap blok yang diangkut. Untuk pengamanan pada bagian sisi atas dari blok digunakan lashing rope yang diikatkan cukup erat pada bagian deck kapal. Untuk pengamanan pada bagian sisi samping dari blok digunakan sistem shoring yaitu suatu bentuk penahan atau pemberhenti agar muatan tidak bergerak dengan menggunakan plat profil I yang dilas ke atas deck kapal. Untuk jarak yang disarankan oleh IMO yaitu pada setiap jarak gading kapal tetapi tidak kurang dari 1 meter [5].
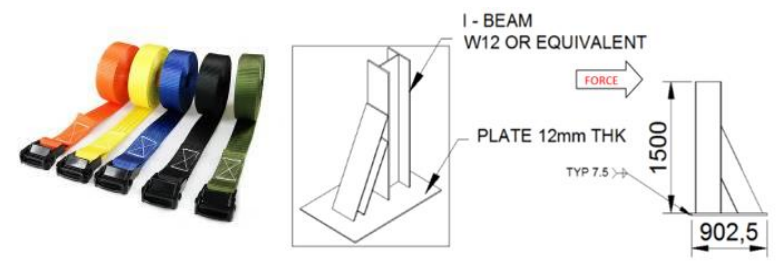

Gambar 4. Lashing Rope dan Plat Profil I.

\section{J. Desain Rencana Garis}

Pembuatan rencana garis (lines plan) menggunakan software pembuatan model kapal. Pembuatan model dilakukan dari pembentukan badan kapal sesuai dengan ukuran utama yang telah dihitung. Perolehan gambar rencana garis didapat dari fitur software tersebut. Hasil rencana garis dapat dilihat pada Gambar 7.

\section{K. Desain Rencana Umum}

Pembuatan rencana umum ini didasari dari kebutuhan tangki yang telah dihitung, kapasitas payload yang telah dihitung, serta ukuran utama yang telah didapat. Hasil rencana umum dapat dilihat pada Gambar 8.

\section{Desain model $3 D$}

Desain model 3D dilakukan dengan bantuan software pembuatan model 3D. Desain model 3D dibuat merujuk dari gambar desain rencana umum. Desain gambar model 3D dapat dilihat pada Gambar 5.
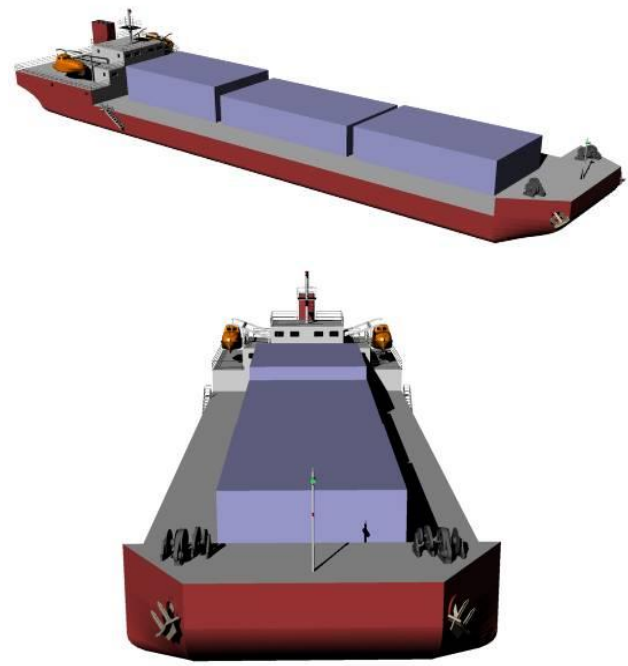

Gambar 5. 3D Model Self-Propelled Barge.

\section{Prosedur Loading \& Off-Loading}

Prosedur loading dan off-loading didapatkan dari karakteristik stabilitas kapal saat sedang mengangkut muatan pada tiap-tiap kondisi atau load case. Kemudian dibuat skema untuk tiap-tiap loading dan off-loading. Skema prosedur loading dapat dilihat pada Gambar 6.
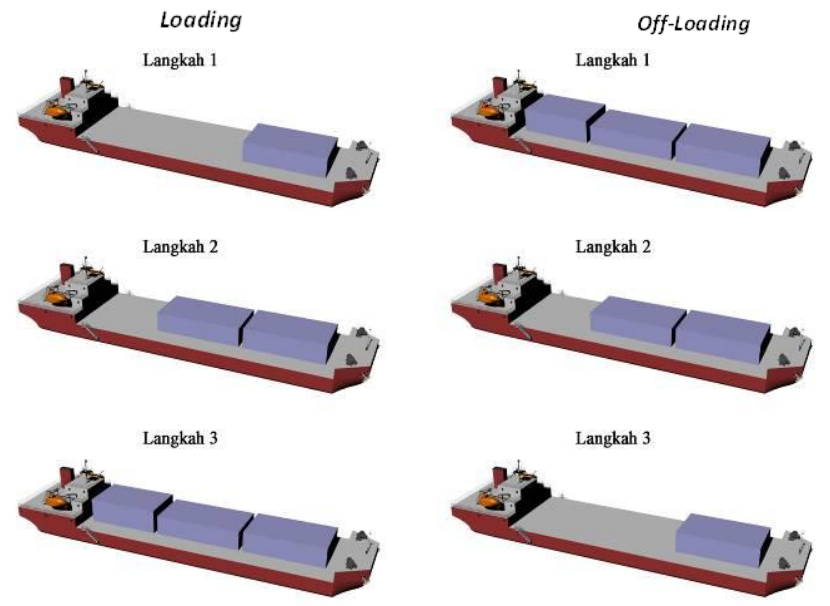

Gambar 6. Skema Loading dan Off-Loading.

\section{ANALISIS EKONOMIS}

Tabel 5.

Hasil Perhitungan Komponen Ekonomis Komponen Ekonomis Nilai 


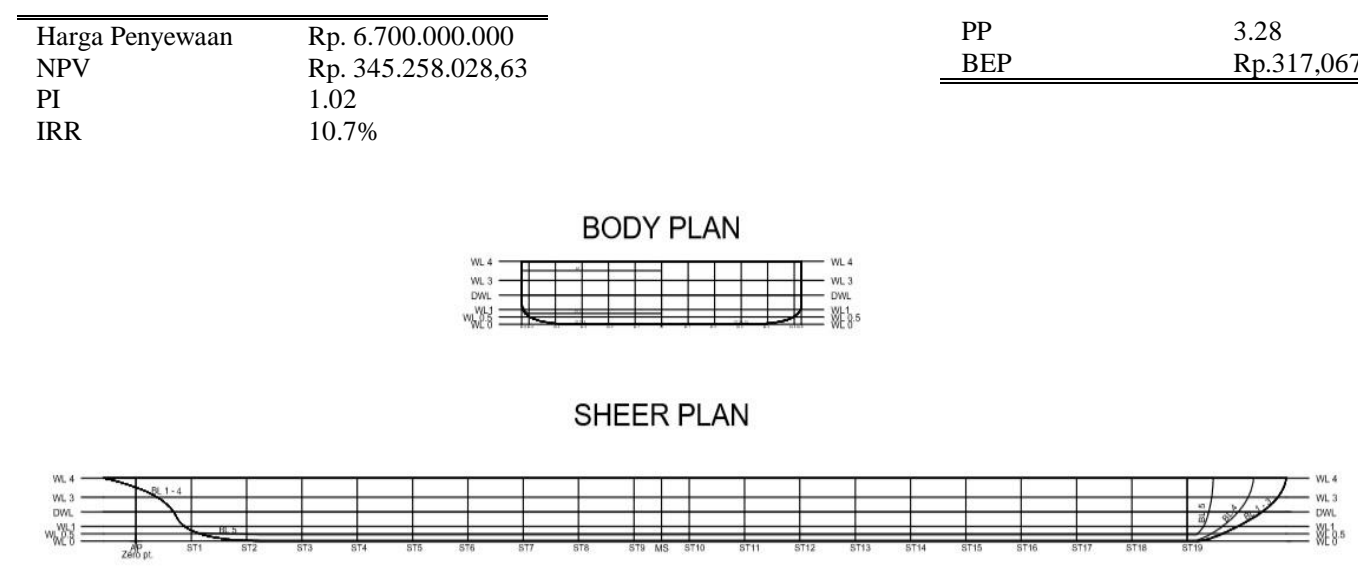

HALF BREADTH PLAN

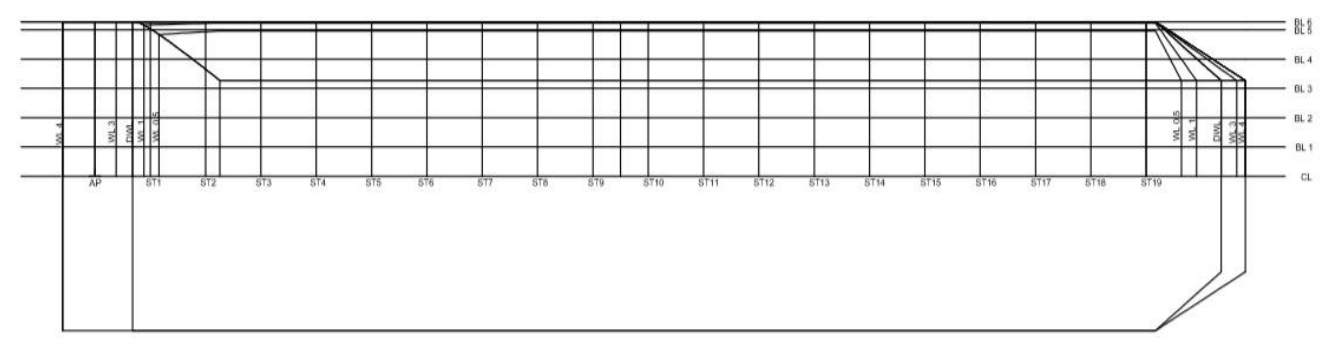

Gambar 7. Rencana Garis Self-Propelled Barge.
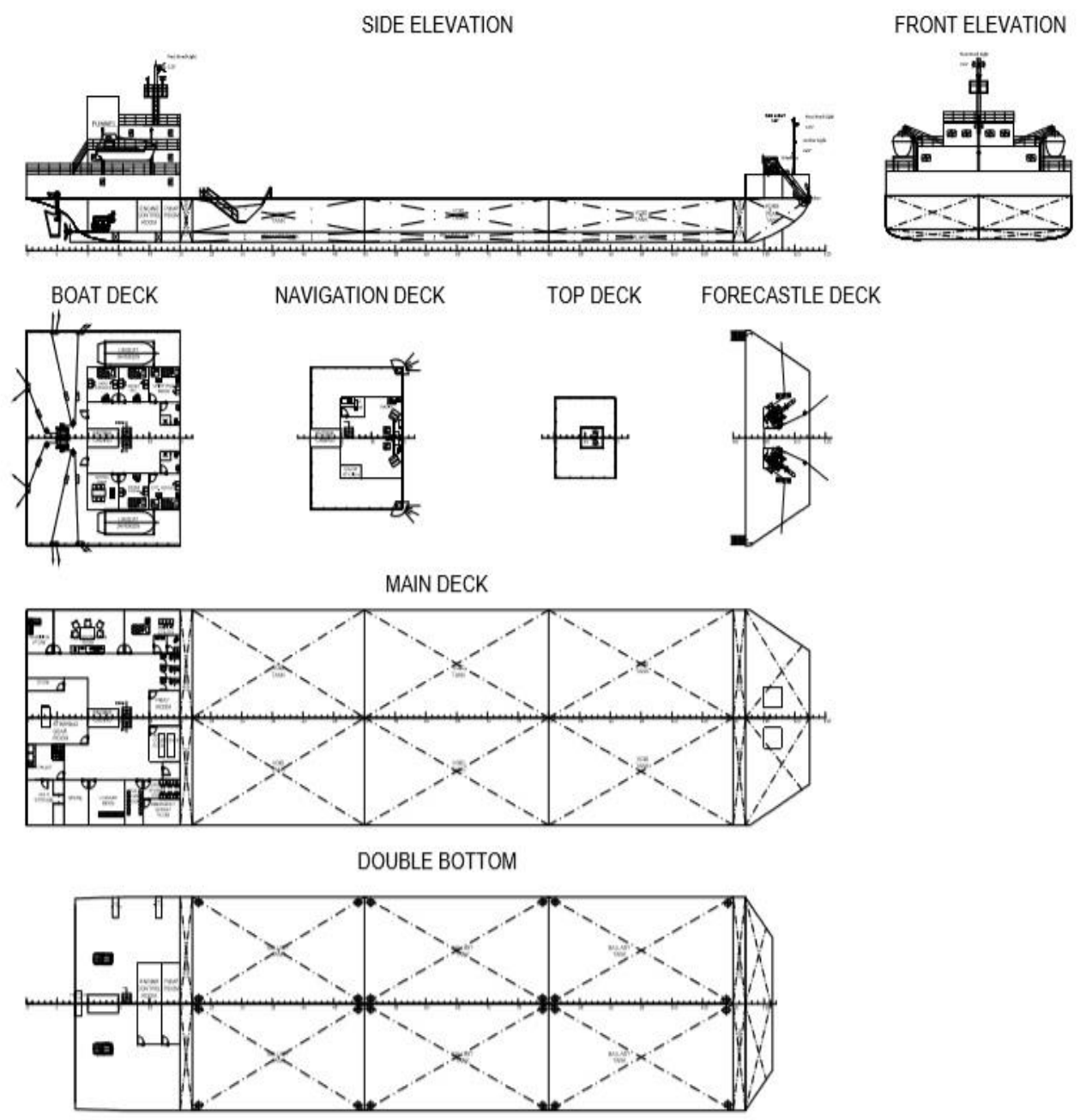
Tabel 6.

Perbandingan Karakteristik Self-Propelled Barge dengan Tongkang dan Tug Boat yang Ada

\begin{tabular}{ccc}
\hline \hline Karakteristik & $\begin{array}{c}\text { Barge dan Tugboat } \\
\text { Existing }\end{array}$ & Self-Propelled Barge \\
\hline Harga & $\begin{array}{c}\text { Rp, 5,540,000,000 (tanpa } \\
\text { Operational Cost) }\end{array}$ & Rp. 6,700,000,000 \\
$\begin{array}{c}\text { Muatan yang } \\
\text { dapat diangkut } \\
\text { Kecepatan } \\
\text { Waktu }\end{array}$ & Blok & Blok dan mesin-mesin \\
pengiriman & $5 \mathrm{knot}$ & $10 \mathrm{knot}$ \\
Utilitas & $4 \mathrm{jam}$ & $2 \mathrm{jam}$ \\
& $\begin{array}{c}\text { Delay Time cukup lama } \\
\text { barena menunggu adanya } \\
\text { blok terlebih dahulu. }\end{array}$ & $\begin{array}{c}\text { Delay Time yang lebih sedikit, } \\
\text { dikarenakan dapat mengangkut } \\
\text { selain blok saat tidak ada blok } \\
\text { yang diangkut }\end{array}$ \\
\hline \hline
\end{tabular}

Perbandingan biaya dilakukan dengan menghitung terlebih dahulu komponen ekonomis dari self-propelled barge ini seperti penentuan biaya penyewaan self-propelled barge, proyeksi arus kas, perhitungan break even point, net present value, profitability index, internal rate of return, serta payback period kemudian dilakukan perbandingan dengan biaya sewa moda transportasi yang sudah ada. Rincian dapat dilihat pada Error! Reference source not found.5.

Perbandingan karakteristik harga dan fungsi dari kapal self-propelled barge ini dengan kapal tongkang dan tug boat yang sudah ada dapat dilihat pada Tabel 6 .

\section{KESIMPULAN}

\section{A. Kesimpulan}

Setelah dilakukan perhitungan dan analisis maka kesimpulan dari Jurnal ini adalah sebagai berikut:

1. Dari analisis teknis didapatkan ukuran utama kapal sebagai berikut:

$$
\begin{array}{ll}
\text { Length of perpendicular }(\mathrm{LPP}) & : 89.2 \text { meter } \\
\text { Breadth }(\mathrm{B}) & : 21.1 \text { meter } \\
\text { Height }(\mathrm{H}) & : 4.3 \text { meter } \\
\text { Draft }(\mathrm{T}) & : 1.5 \text { meter }
\end{array}
$$

2. Kapal self-propelled barge ini memenuhi persyaratan stabilitas kapal, trim, dan freeboard.

3. Desain Rencana Garis dapat dilihat pada lampiran , Desain Rencana Umum dapat dilihat pada lampiran , dan Desain 3D dapat dilihat pada lampiran

4. Harga penyewaan self-propelled barge ini sebesar Rp. $6,700,000,000$.

\section{DAFTAR PUSTAKA}

[1] M. . Parsons, Parametric Design (Chapter 11). Michigan: University of Michigan, 2001.

[2] R. Alfazer, "Desain Self-Propelled Barge Sebagai Fasilitas Apung Bergerak Pengolah Limbah Bahan Berbahaya dan Beracun (B3) di Teluk Jakarta," Surabaya, 2017.

[3] I. M. Organization, International Convention for the Safety of Life at Sea. London: IMO, 1988.

[4] I. M. Organization, Intact Stability (IS) Code. London: IMO, 2008.

[5] International Maritime Organization, "Code of Safe Practice for Cargo Stowage and Securing," London, 1988. 